\title{
Ludvík Kundera stoletý
}

Ludvík Kundera (22. března 1920 - 17. srpna 2010), muž mnoha uměleckých profesí, je znám především jako český básník a překladatel z němčiny. Byl však umělecky činný i v dalších oblastech slovesné kultury a výtvarného umění. Psal rovněž dramata, rozhlasové a televizní hry, eseje, odborné stati o výtvarném umění, o uměleckých směrech a výtvarných umělcích, vystavoval své výtvarné a fotografické práce, editoval, překládal z řady evropských jazyků. Jako editor a překladatel do němčiny zprostředkovával českou lyriku v několika knižních publikacích německojazyčnému prostředí.

Pokud je mi známo, nejvíce překladů do češtiny realizoval Ludvík Kundera z němčiny. Připomenu ty nejvýznamnější: básně, dramata, prózy a stati Bertolta Brechta (často ve spolupráci s Rudolfem Vápeníkem), básně Georga Trakla, Hanse Arpa, Petera Huchela, Gottfrieda Benna, vybrané básně Rainera Marii Rilka, Christiana Morgensterna nebo Güntera Eicha. Pro potřeby různých divadelních scén přeložil řadu dramatických textů od Schillera přes Büchnera po Petera Weiße. Známé a mezi znalci staly se populární jeho překlady expresionistů, zvláště výbor Haló, je tady vichr, vichřice! (1969).

Další obsáhlou oblastí překladové literatury tvoří překlady z francouzštiny: vedle Apolllinaira a Eluarda i dnes zapomenutý Robert Desnos nebo René Char. Dnes již není př́liš známo, že v šedesátých letech byly českou překladovou kritikou velmi ceněny Kunderovy překlady ze slovenštiny, především básně Ladislava Novomeského (Otevřená okna, 1964; Poémy, 1965). Ve své době se dočkaly pozitivního ohlasu i Kunderovy překlady z bulharštiny (Christo Smirnenski, 1953; Nikola Vapcarov) a z ruštiny (Eduard Bagrickij, 1959 a 1983), vždy šlo o lyriku. Na překladech ze slovinštiny a srbocharvátštiny spolupracoval L. Kundera s lingvisty (knižně se překlady objevily v r. 1962 a 1966). Také pro překlady z jiných jazyků využíval takzvané interlineární překlady, tak nalezneme Kunderovo jméno i pod překlady básní z mad’arštiny, italštiny a rumunštiny. Př́ležitostně překládal též ze severských jazyků. Od sedmdesátých let 20. století začaly se objevovat i Kunderovy překlady z češtiny do němčiny; zde je nutno připomenout antologie české lyriky Die Sonnenuhr, 1987, pro niž L. Kundera přeložil např. básně Viléma Závady, Františka Halase, Vítězslava Nezvala, Josefa Kainara, Jaroslava Seiferta, nebo knihu Adieu Musen. Anthologie des Poetismus (2004).

Sté výročí narození Ludvíka Kundery, který se do existence Masarykovy univerzity zapsal i jako její pedagog v popřevratových letech, připomeneme 
přetiskem někdejšího rozhovoru s Ludvíkem Kunderou pro studentský časopis FORUM, vydávaný bohemisty brněnské filozofické fakulty v osmdesátých letech dvacátého století. Byla to pro Ludvíka Kunderu po čtrnácti letech umlčování první příležitost poskytnout interview české kulturní veřejnosti.

Zbyněk Fišer 